\title{
Success story on Alternate wetting and Drying irrigation in Rice
}

\author{
K. Sridhar, P. Archana*, and A. Rama Krishna Babu \\ DAATTC, Mahabubnagar, India \\ *Corresponding author
}

\begin{tabular}{|l|}
\hline Ke y w o r d s \\
$\begin{array}{l}\text { Alternate } \\
\text { wetting and } \\
\text { drying }\end{array}$ \\
\hline Article Info \\
\hline $\begin{array}{l}\text { Accepted: } \\
\text { 08 January } 2020 \\
\text { Available Online: } \\
\text { 10 February } 2020\end{array}$ \\
\hline
\end{tabular}

A B S T R A C T

The present study was carried out in Narasimhulu farmer field in Nellikondi village of China Chinta Kunta Mandal of Mahabubnagar District. The progressive farmers has succeeded with good result by adopting the alternate wetting and drying method of scheduling the irrigation in Rice. He has irrigated the field 39 times following the Alternate Wetting and drying method of irrigation in contrast to 52 irrigations under traditional flood irrigation saving the water by 24 per cent. Mr. C.Narasimhulu was very much satisfied with his practice of Alternate Wetting and Drying irrigation in Rice as he achieved good yields even by adopting the water saving technology which has boosted his confidence and as an progressive farmer with self-motivation he has spread this technology even to small farmers in the village and motivated fellow farmers in the village and allowed other farmers to visit his field from surrounding villages Fareedpur, Ammapur, Undyala, Muchintala villages of CC Kunta mandal.

\section{Introduction}

\section{Situation and Problem identified}

Nellikondi Village is located $38 \mathrm{KM}$ far from District head quarters Mahabubnagar towards southern side and 5KM from mandal head quarters Chinnachintakunta. The total area of the village is 2225 acres out of which the cultivated area is 1717 acres constituting 270 acres under irrigation and 1440 under rainfed situation. The main soil types in the village are sandy loams, clay loam soils with patches of saline soils. The main sources of irrigation are borewell and two canals i.e Peddavagu in the village where water comes from Koilsagar and Chinnavagu water comes from Jurala, which are occasionally useful for irrigation. The main crops in the village are Rice, Cotton and Redgram. Rice area is under with bore well irrigation. Water availability in these bore wells depends on monsoonal rainfall.

Generally, about $3000-5000$ litres of water is 
required to produce one $\mathrm{kg}$ of rice, which is about two to three times higher than to produce one kilogram of other cereals. (Azarpour et al., 2011).

However availability of water resources is expected to decline in the years to come (Perveen et al., 2012). In this scenario, saving water and utilizing the available water in judicious manner is highly essential in paddy fields. In this context, DAATT Center Mahabubnagar initiated Alternate Wetting and Drying scheduling system of irrigation since 2017 with the support given by Water Technology center, Rajendranagar Hyderabad. As an initiative, DAATTC has implemented this programme in five villages with 40 farmers in the Mahabubnagar District. Among them, Mr. C. Narasimhulu one of the progressive farmers has succeeded with good result by adopting the alternate wetting and drying method of scheduling the irrigation in Rice.

\section{Technology intervention and its description}

Rice crop is not an aquatic plant but can survive under waterlogged condition. Reducing water input in rice production can have a high societal and environmental impact if the water saved can be diverted to areas where competition is high (Klemm, 1999). Alternate Wetting and Drying is an irrigation technique where water is applied to the field a number of days after disappearance of ponded water based on the visual observation of drop in the water level in the perforated casing pipe. (Tuong, 2007).

This is in contrast to the traditional irrigation practice of continuous flooding (i.e., never letting the ponded water disappear). This means that the rice fields are not kept continuously submerged, but are allowed to dry intermittently during crop growth period of rice.(Tabbal et al.,2002). A practical way to implement AWD irrigation practice safely is by using a field water tube made of PVC pipe having $40 \mathrm{~cm}$ length and $15 \mathrm{~cm}$ in diameter to monitor the receding water depth on the field. Adopting water saving method like Alternate Wetting and Drying is very appropriate for realizing optimum yields with less water by irrigating more area with the available irrigation water. In this manner, $\mathrm{C}$. Narsimhulu has irrigated the field 39 times following the Alternate Wetting and drying method of irrigation in contrast to 52 irrigations under traditional flood irrigation saving the water by 24 per cent.
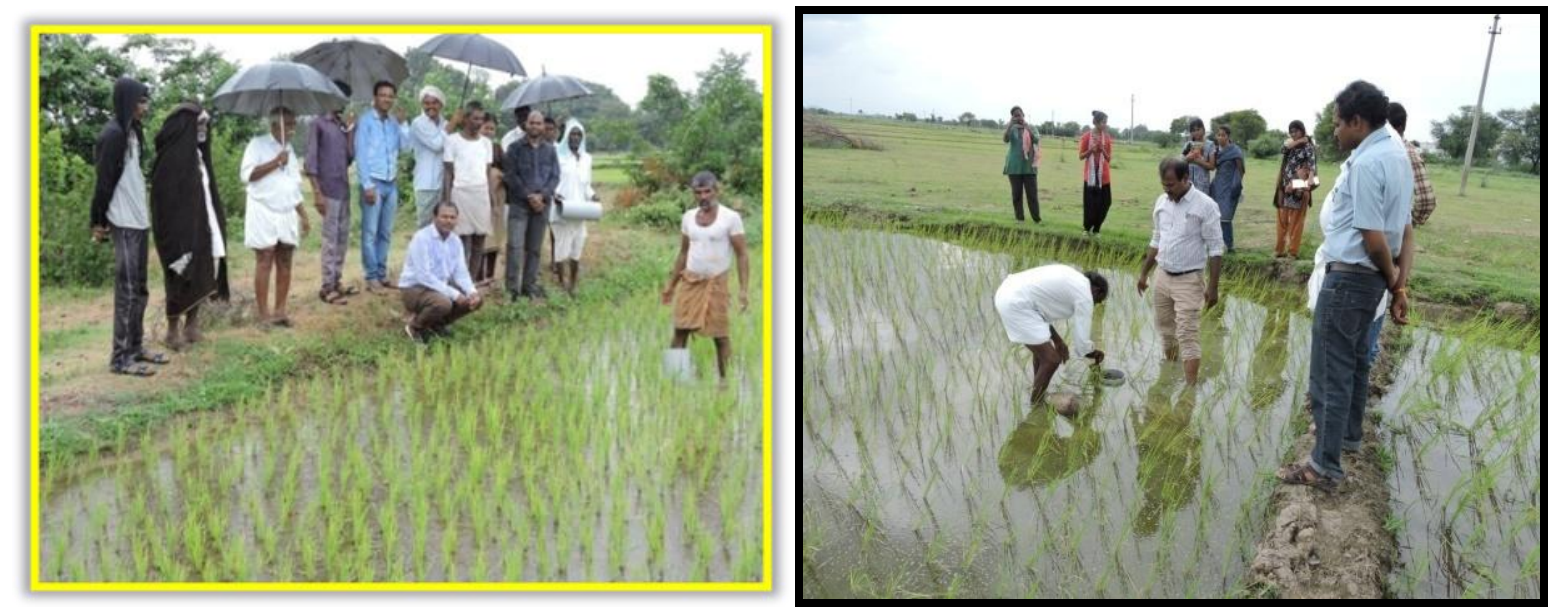

Fig.1 Demonstrating installation of AWD perforated casing pipe in the field 


\section{Methodology approach}

First we entered in to the village through awareness programme on Alternate Wetting and Drying irrigation in Rice crop with small group of farmers as an entry point activity during Rabi- 2018.

During conversation, the farmer Mr. C.Narasimhulu who is very enthusiastic to adopt innovative technologies has approached DAATTC scientist for suggestions on practicing Alternate Wetting and Drying irrigation in Rice.

\section{Cost of technology intervention:}

Normal cost of cultivation as that of traditional flood method of irrigation per the farmer's reference in the village including land preparation, seed cost, nursery raising, transplanting, fertilizer, weeding, pesticides and harvest is around Rs. 15440/- per acre on an average was recorded.

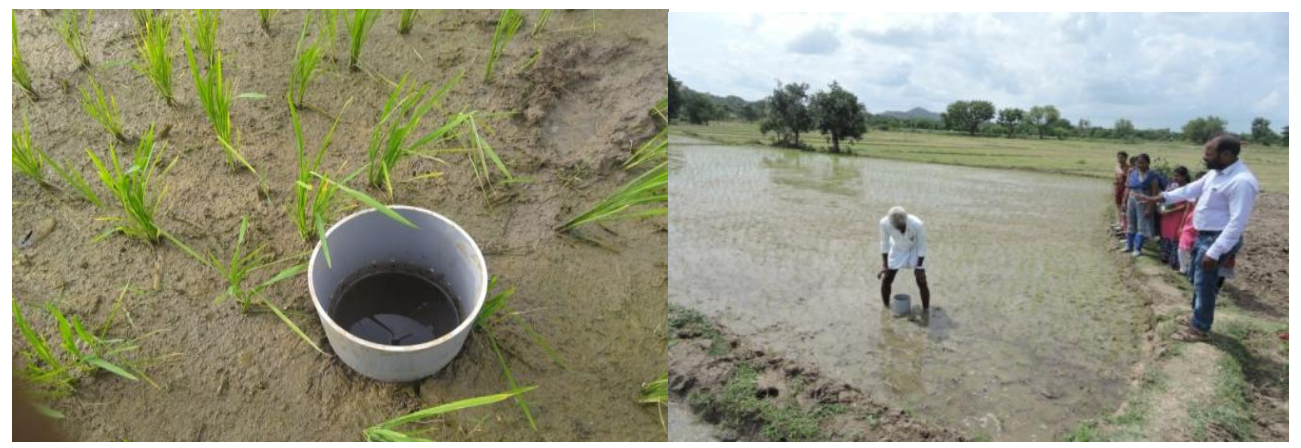

Fig.2 Demonstrating installation of AWD perforated casing pipe in the field
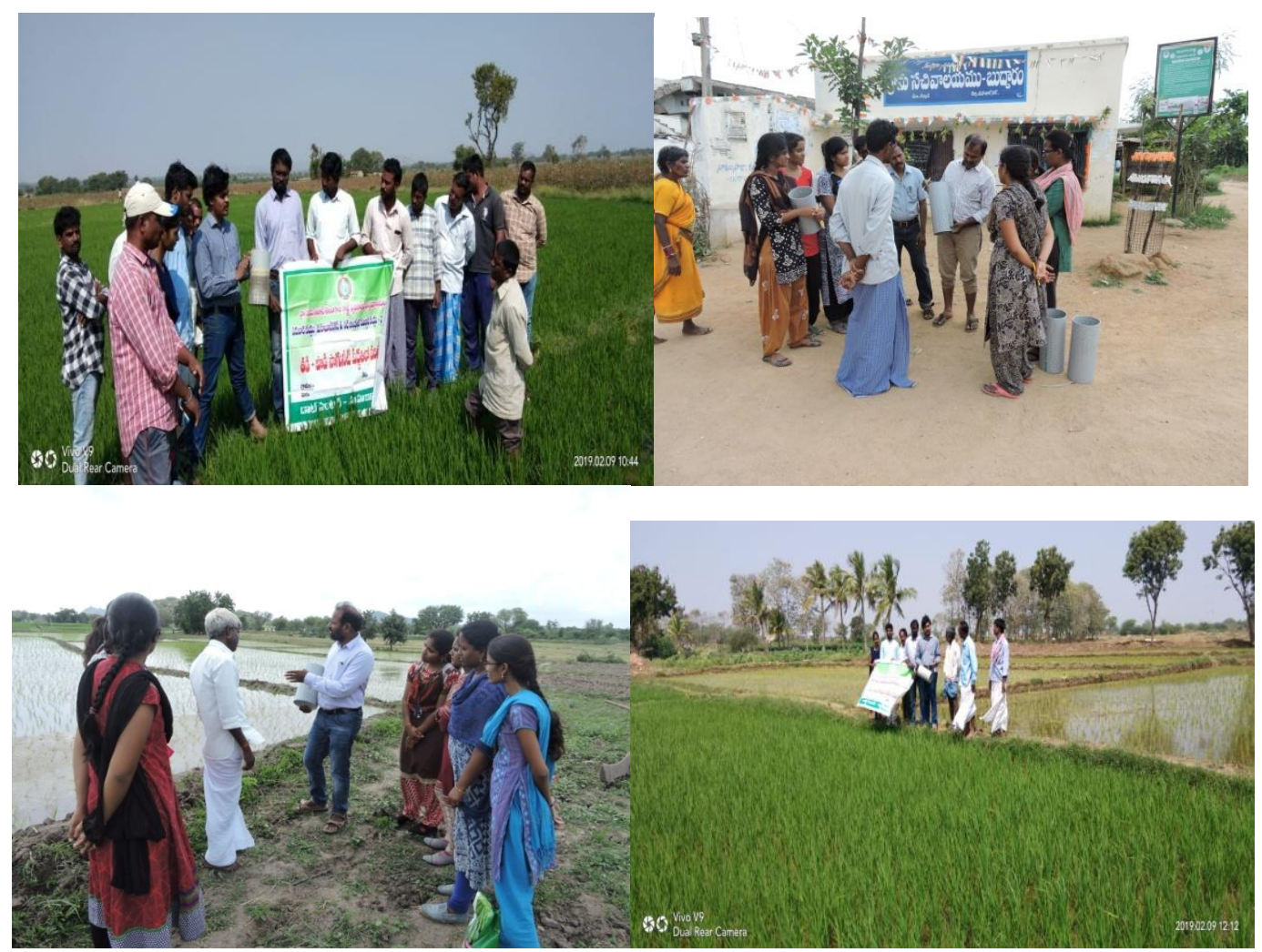

Fig.3 Group discussion with farmers on AWD technology 
Table.1

\begin{tabular}{|l|l|c|c|c|c|}
\hline Crop & $\begin{array}{l}\text { Improved water management } \\
\text { technologies adopted }\end{array}$ & $\begin{array}{c}\text { No. of } \\
\text { irrigations }\end{array}$ & $\begin{array}{c}\text { Percent saving } \\
\text { in water }\end{array}$ & $\begin{array}{c}\text { Yield } \\
\text { (Kg./acre) }\end{array}$ & $\begin{array}{c}\text { Cost of Cultivation } \\
\text { (Rs./acre) }\end{array}$ \\
\hline Rice & $\begin{array}{l}\text { Alternate wetting and drying } \\
\text { irrigation in Rice using AWD } \\
\text { perforated pipe }\end{array}$ & 39 & 24 & 2730 & 15440 \\
\hline & \begin{tabular}{l} 
Traditional flood irrigation \\
\hline
\end{tabular} & 52 & & & \\
\hline
\end{tabular}

\section{Economic benefit due to Technology} intervention

The farmer has cultivated 5 acres of Rice crop with the same amount of water that he generally uses for cultivating 3 acres of Rice with traditional flood irrigation.

In this manner he has achieved an increased net income of about 25,000/- from additional 2 acres of land brought under cultivation under Rice with the available water from the existing bore well during Rabi 2018-19. He has also achieved optimal yield even with reduced irrigation water.

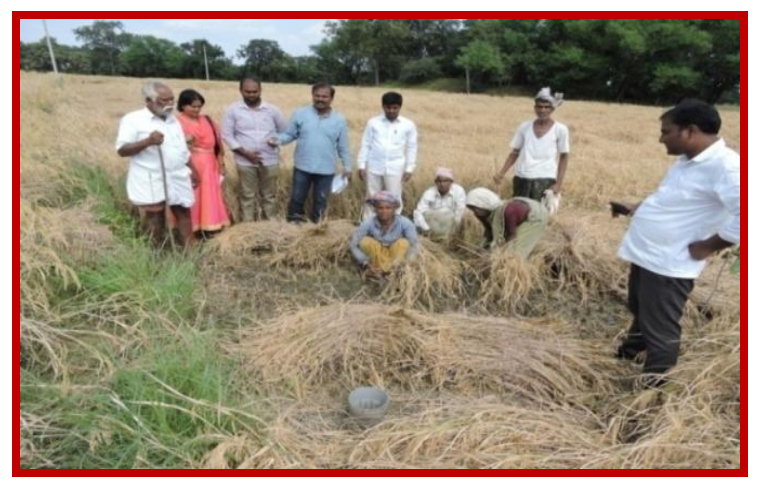

Fig.4 Recording straw yield in demonstration plot

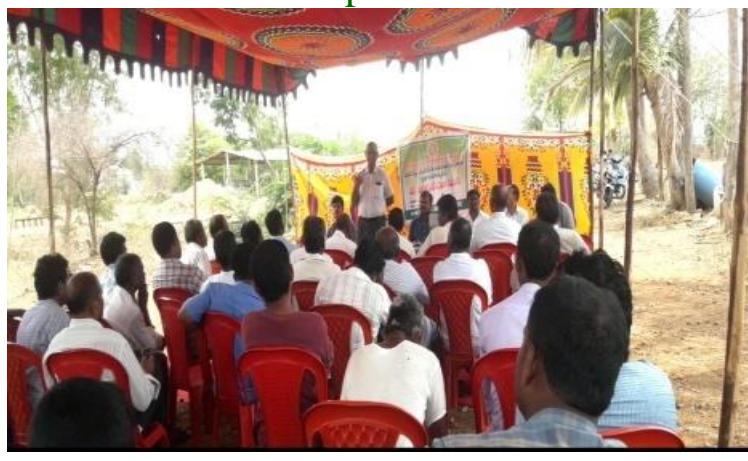

Fig.5 Field day on AWD technology
Impact on livelihoods/ Socio economic condition of the farmer

Mr. C.Narasimhulu was very much satisfied with his practice of Alternate Wetting and Drying irrigation in Rice as he achieved good yields even by adopting the water saving technology which has boosted his confidence and as an progressive farmer with selfmotivation he has spread this technology even to small farmers in the village and motivated fellow farmers in the village and allowed other farmers to visit his field from surrounding villages Fareedpur, Ammapur, Undyala, Muchintala villages of CC Kunta mandal.

\section{Feedback of the farmers}

Farmers expressed that the crop growth was very promising with good tillering, with lower pest and diseases load and easy technique for saving water. Other farmers opined that the technology is very useful to farmers with limited water source under bore wells.

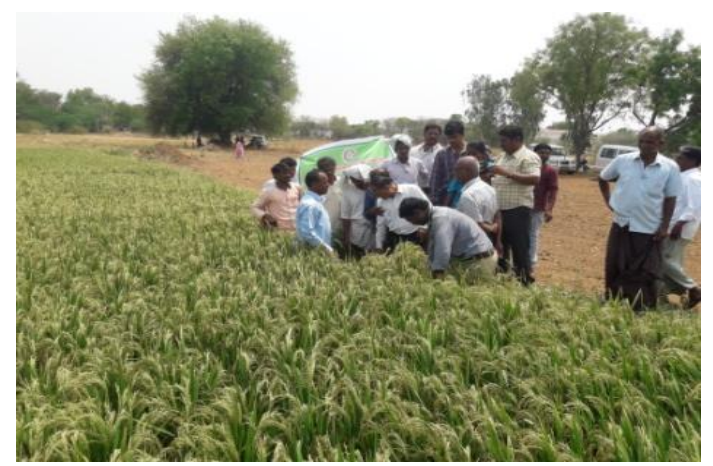

Fig.6 Field day on AWD technology 


\section{Farmers express their satisfaction about Sustainability}

Adoption of Alternate Wetting and Drying irrigation is easy provided farmer is convinced to the fact that Rice crop can be cultivated without continuous submergence of water in the field. At par yields with traditional flood method of irrigation are key to sustain this technology.

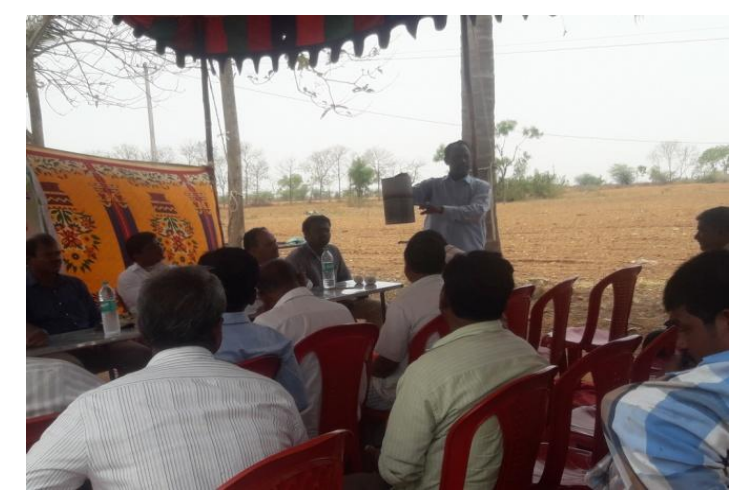

Fig.7 Farmer Narsimhulu explaining about the technology

\section{Lessons learnt}

Awareness programmes will change the farmer's attitude towards adoption of new technologies. There is every chance to reduce the water requirement of Rice by adopting such water saving techniques as shortage of water will continue to hamper the agriculture in the future.

The success story of C. Narasimhulu paves way for other Rice farmers in increasing the area under Rice with the available water resources for sustainable Rice production.

\section{References}

Azarpour, E., Tarighi, F., Moradi, M and Bozorgi, H.R. 2011. Evaluation effect of different nitrogen fertilizer rates under irrigation management in rice farming. World Applied Science Journal. 13(5): 1248-1252.

Klemm, W. 1999. Water saving in rice cultivation. In: Assessment and Orientation Towards the 21st Century. Proceedings of 19th Session of the International Rice Commission, Cairo, Egypt, 7-9 September 1999. FAO, Rome, pp. 110-117.

Perveen, S., Krishnamurthy, C.K., Sidhu, R.S., Vatta, K., Balijnder, K., Modi, V., Fishman, R., Polycarpous, L and Lall, U. 2012. Restoring groundwater in Punjab, India's breadbasket: Finding agricultural solution for water sustainability. Columbia water center white paper. 12 .

Tuong, T. P. 2007. Alternate Wetting and Drying Irrigation (AWD): a technology for water saving in rice production. Paper presented at the Crop Cutting Ceremony, BADC Farm, Modhupur, Tangail.

Tabbal, D.F., Bouman, B.A.M., Bhuiyan, S.I., Sibayan, E.B and Sattar, M.A. 2002. On-farm strategies for reducing water input in irrigated rice. Agricultural Water Management. 56(2): 93-112.

\section{How to cite this article:}

Sridhar. K, P. Archana, and Rama Krishna Babu. A. 2020. Success story on Alternate wetting and Drying irrigation in Rice. Int.J.Curr.Microbiol.App.Sci. 9(02): 1040-1044. doi: https://doi.org/10.20546/ijcmas.2020.902.121 